\title{
RanBP2-Like and GRIP Domain-Containing Protein 3
}

National Cancer Institute

\section{Source}

National Cancer Institute. RanBP2-Like and GRIP Domain-Containing Protein 3. NCI

Thesaurus. Code C143084.

RanBP2-like and GRIP domain-containing protein 3 (1758 aa, $197 \mathrm{kDa}$ ) is encoded by the human RGPD3 gene. This protein may play a role in the localization of GTP-binding nuclear protein Ran. 